\title{
Intra-tracheal administration of a naked plasmid expressing stromal derived factor-1 improves lung structure in rodents with experimental bronchopulmonary dysplasia
}

Kasonya Guerra ${ }^{1,2}$, Carleene Bryan ${ }^{1,2}$, Frederick Dapaah-Siakwan ${ }^{1,2}$, Ibrahim Sammour ${ }^{1,2}$, Shelly Drummond ${ }^{1,2}$, Ronald Zambrano ${ }^{1,2}$, Pingping Chen ${ }^{1,2}$, Jian Huang ${ }^{1,2}$, Mayank Sharma ${ }^{1,2}$, Sebastian Shrager ${ }^{1}$, Merline Benny ${ }^{1,2}$, Shu $\mathrm{Wu}^{1,2}$ and Karen C. Young ${ }^{1,2,3^{*}}$

\begin{abstract}
Background: Bronchopulmonary dysplasia (BPD) is characterized by alveolar simplification and disordered angiogenesis. Stromal derived factor-1 (SDF-1) is a chemokine which modulates cell migration, proliferation, and angiogenesis. Here we tested the hypothesis that intra-tracheal (IT) administration of a naked plasmid DNA expressing SDF-1 would attenuate neonatal hyperoxia-induced lung injury in an experimental model of BPD, by promoting angiogenesis.
\end{abstract}

Design/methods: Newborn Sprague-Dawley rat pups ( $n=18-20 /$ group) exposed to room air (RA) or hyperoxia (85\% O2) from postnatal day (P) 1 to 14 were randomly assigned to receive IT a naked plasmid expressing SDF-1, JVS-100 (Juventas Therapeutics, Cleveland, Ohio) or placebo (PL) on P3. Lung alveolarization, angiogenesis, inflammation, vascular remodeling and pulmonary hypertension $(\mathrm{PH})$ were assessed on $\mathrm{P} 14$. $\mathrm{PH}$ was determined by measuring right ventricular systolic pressure (RVSP) and the weight ratio of the right to left ventricle + septum (RV/ LV + S). Capillary tube formation in SDF-1 treated hyperoxia-exposed human pulmonary microvascular endothelial cells (HPMEC) was determined by matrigel assay. Data is expressed as mean \pm SD and analyzed by two-way ANOVA.

Results: Exposure of neonatal pups to 14 days of hyperoxia decreased lung SDF-1 gene expression. Moreover, whilst hyperoxia exposure inhibited capillary tube formation in HPMEC, SDF-1 treatment increased tube length and branching in HPMEC. PL-treated hyperoxia-exposed pups had decreased alveolarization and lung vascular density. This was accompanied by an increase in RVSP, RV/LV $+S$, pulmonary vascular remodeling and inflammation. In contrast, IT JVS-100 improved lung structure, reduced inflammation, PH and vascular remodeling.

Conclusions: Intratracheal administration of a naked plasmid expressing SDF-1 improves alveolar and vascular structure in an experimental model of BPD. These findings suggest that therapies which modulate lung SDF-1 expression may have beneficial effects in preterm infants with BPD.

Keywords: Bronchopulmonary dysplasia, Hyperoxia, Angiogenesis, Stromal derived factor-1

\footnotetext{
*Correspondence: Kyoung3@med.miami.edu

'Department of Pediatrics, University of Miami Miller School of Medicine,

1580 NW 10th Avenue RM-344, Miami, FL 33136, USA

2Batchelor Children's Research Institute, University of Miami Miller School of

Medicine, 1580 NW 10th Avenue RM-344, Miami, FL 33136, USA

Full list of author information is available at the end of the article
}

(c) The Author(s). 2019 Open Access This article is distributed under the terms of the Creative Commons Attribution 4.0 International License (http://creativecommons.org/licenses/by/4.0/), which permits unrestricted use, distribution, and reproduction in any medium, provided you give appropriate credit to the original author(s) and the source, provide a link to the Creative Commons license, and indicate if changes were made. The Creative Commons Public Domain Dedication waiver (http://creativecommons.org/publicdomain/zero/1.0/) applies to the data made available in this article, unless otherwise stated. 


\section{Background}

Bronchopulmonary dysplasia (BPD) is the leading cause of chronic lung disease in infancy. Since its first description in 1967 [1], the incidence of BPD has remained high as more extremely low birth weight premature infants survive [2-4] and few therapeutic interventions have reduced the disease burden. BPD survivors have an increased risk of pulmonary hypertension (PH), growth failure, neuro-developmental delay and other long-term sequelae causing a significant impact on families and health care systems $[5,6]$. Inflammation and altered angiogenic signaling play a key role in the development of BPD [7] and strategies which modulate these pathways may reduce $\mathrm{BPD}$ incidence.

Stromal derived factor-1 (SDF-1), also called chemokine ligand 12 (CXCL12), is a small pleiotropic molecule belonging to the CXC chemokine family. It is encoded by the CXCL12 gene on chromosome 10 and is constitutively expressed by many tissues and cell types [8]. Its main receptors are chemokine receptor 4 (CXCR4) and chemokine receptor 7 (CXCR7). Within the lung, SDF-1 is expressed by several cell types including the epithelium, while its receptors CXCR4 and CXCR7 are expressed on vascular endothelial cells. In addition, CXCR7 is also expressed on the epithelium [9-11]. SDF-1 signaling culminates in a multitude of biological functions including modulation of chemotaxis, proliferation, apoptosis, survival, and differentiation $[12,13]$.

SDF-1 plays an important role in organogenesis and early development. SDF-1 knockout mice exhibit embryonic lethality with survivors having cardiac defects, impairment in B-cell lymphopoiesis and bone marrow myelopoiesis during embryonic development [14]. CXCR4 deficient mice die perinatally and have similar defects in hematopoietic and cerebellar development [15]. Additionally, CXCR7 knockout mice die postnatally with survivors having cardiac abnormalities [10]. In the lung, SDF-1 conditional knockout neonatal mice have abnormal lung structure with an increase in alveolar spaces, whilst adult mice exhibit emphysematous changes in lung morphology [16].

The role of SDF-1 in organ injury and repair has been controversial. Indeed, while several reports demonstrate that SDF-1 and/or its receptors promote repair of the injured kidney, liver, limb, brain and retina [17-23] by mobilizing endothelial progenitor cells to injury sites [22, 24, 25] or upregulating vascular endothelial growth factor (VEGF) and other angiogenic factors [26], in adult lung disease models, SDF-1/CXCR4 signaling potentiates lung inflammation and CXCR4 antagonism attenuates lung inflammation and injury $[27,28]$. Xu and colleagues [27] demonstrated that SDF-1 levels and CXCR4 ${ }^{\text {pos }}$ cells are increased in patients with idiopathic pulmonary fibrosis and antagonism of CXCR4, attenuates bleomycininduced lung fibrosis. Conversely, SDF-1 inhibition impairs alveolar epithelial cell spreading and delays resolution of permeability after lung injury [29] and agonism of the SDF-1 receptor, CXCR7, prevents epithelial damage, promotes alveolar repair and reduces bleomycin-induced pulmonary fibrosis [30]. There is also new evidence demonstrating that platelet-derived SDF-1 plays a crucial role in lung regeneration after pneumonectomy [31]. While these discrepancies maybe secondary to differences in the models of injury as well as the relative concentration and structural conformation of SDF-1, more recent reports show differential signalling of SDF-1 through its receptors during the acute and chronic stages of injury [30].

Whether SDF-1 modulates neonatal hyperoxia-induced lung injury was heretofore unknown. SDF-1 protein expression is however unchanged in neonatal rodents exposed to hyperoxia suggesting that suboptimal SDF-1 lung levels may blunt the intrinsic reparative response following neonatal hyperoxia exposure [32]. In the present study, we hypothesized that augmentation of the intrinsic SDF-1 response in neonatal rodents exposed to hyperoxia, by intra-tracheally (IT) administering a naked plasmid DNA expressing SDF-1 (JVS-100), would attenuate lung injury by promoting angiogenesis. JVS-100 (Juventas Therapeutics, Cleveland, Ohio) is a non-viral gene therapy engineered to express SDF-1. In a porcine model, JVS-100 was effectively delivered to the myocardium with efficient gene uptake and significant gene expression [33]. The safety and potential efficacy of JVS-100 in patients with ischemic cardiomyopathy have also been shown in recent phase 1 and 2 clinical trials [34, 35].We demonstrate increased capillary tube formation following SDF-1 treatment of hyperoxia-exposed pulmonary microvascular endothelial cells (HPMECs). In a neonatal rodent model of BPD, we demonstrate that IT JVS-100 improves angiogenesis, attenuates $\mathrm{PH}$ and decreases inflammation. These findings suggest a potential therapeutic role of SDF-1 in the repair of the injured preterm lung.

\section{Materials and methods \\ Animals}

Pregnant Sprague Dawley rats were purchased from Charles River Laboratories (Wilmington, MA). Animals were treated according to National Institute of Health $(\mathrm{NIH})$ guidelines for the use and care of laboratory animals following approval of the study protocol by the University of Miami Animal Care and Use Committee.

\section{Experimental design}

Sprague Dawley pups assigned to normoxia (RA) or hyperoxia $\left(85 \% \mathrm{O}_{2}\right)$ from postnatal day $(\mathrm{P}) 1$ to $\mathrm{P} 14$ were randomly assigned to receive intratracheal (IT) injections of a plasmid expressing SDF-1 (JVS-100;100 $\mu \mathrm{g} / 50 \mu \mathrm{l}$ ) or phosphate buffered saline as placebo (PL) on P3. This dose was chosen following pilot studies in our laboratory. Following 
anesthesia with isoflurane, the trachea was exposed through a small incision in the midline of the neck, and IT JVS-100 or PL were delivered by tracheal puncture with a 30-gauge needle. The incision was closed with Vetbond ${ }^{\mathrm{m}}$ tissue adhesive ( $3 \mathrm{M}$, St. Paul, MN) and the pups were allowed to recover within a warmed plastic chamber. Oxygen exposure was achieved in a Plexiglas chamber by a flow-through system and the oxygen level inside the chamber was monitored daily with a Maxtec oxygen analyzer (Model OM25RME; Maxtec, Salt Lake City, Utah). Mothers were rotated every $48 \mathrm{~h}$ between the hyperoxia and normoxia chambers to prevent damage to their lung. Litter size was adjusted to 10-12 pups to control for the effect of litter size on nutrition and growth. Hemodynamic measurements, lung morphometric and molecular studies were performed on P14.

In a subgroup of animals in order to determine whether IT administration of a plasmid would be an efficient technique to deliver SDF-1 to the lungs, pups received IT injections of a naked plasmid encoding luciferase (pLuc$100 \mu \mathrm{g} / 50 \mu \mathrm{l})$ on P3. On P5 and 14, luciferin $(150 \mathrm{mg} / \mathrm{kg})$ was injected intraperitoneally (IP). The pups were anesthetized using $4 \mathrm{ppm}$ of inhaled isoflurane via the VetFlo anesthesia system (Kent Scientific Corp, Torrigton,CT) and real-time images using Xenogen IVIS Spectrum (PerkinElmer, Inc. Waltham, MA) were obtained. Following imaging, pups were euthanized and the lungs removed for immunostaining and molecular studies.

\section{Lung morphometric analysis}

Pulmonary morphometry was performed as previously described [36]. Briefly, the trachea and pulmonary artery were perfused and fixed overnight in $4 \%$ paraformaldehyde and embedded in paraffin. Serial sections $5 \mu \mathrm{m}$ thick were taken from the upper and lower lobes and stained with hematoxylin and eosin. Images from randomly selected, non-overlapping parenchymal fields were acquired from lung sections of each animal using an Olympus Qcolor 3 color camera interfaced with a light microscope (Model Leica DMI 4000B). Alveolarization was determined by calculating the radial alveolar count and septal thickness. The number of alveoli transected by a perpendicular line drawn from the center of a respiratory bronchiole to the nearest septal division or pleural margin was used to determine the radial alveolar count. Septal thickness was assessed on hematoxylin and eosin stained lung sections by averaging 100 measurements per 10 representative fields at X 400 magnification.

\section{Pulmonary vascular density}

Vascular density was evaluated as previously described [37]. Lung sections were de-paraffinized, rehydrated, and stained with polyclonal rabbit anti-human Von Willebrand Factor (vWF,1:200; Dako Corp, Carpintaria, CA). The number of vessels $(20-50 \mu \mathrm{m}$ diameters $)$ per high power field (HPF) was quantified in 5 randomly selected, non-overlapping, parenchymal fields from lung sections of each animal.

\section{Pulmonary vascular remodeling}

Pulmonary vascular remodeling was evaluated as previously described [36]. Briefly, lung sections were stained with polyclonal rabbit anti-human vWF (Dako), mouse anti $\alpha$-smooth muscle actin (SMA,1:500; Sigma, St Louis, $\mathrm{MO}$ ) and 4',6-diamidino-2-phenylindole (DAPI, Vector Biolabs, Burlingame, CA). The percentage of peripheral pulmonary vessels $(<50 \mu \mathrm{m}$ in diameter $)$ stained with $\alpha$ SMA $>50 \%$ of the circumference was determined from ten random images on each lung section and all analyses were performed by a blinded observer.

\section{Hemodynamic studies}

Pups were anesthetized and right ventricular systolic pressure (RVSP) evaluated as previously described [36]. Briefly, a thoracotomy was performed and a 22 gauge needle connected to a pressure transducer was inserted into the right ventricle. RVSP was measured and recorded on a Gould polygraph (Model TA-400, Gould instruments, Cleveland,OH). Right ventricular hypertrophy $(\mathrm{RVH})$ was determined by measuring the weight ratio of the right ventricle (RV) to the left ventricle (LV) and septum (S).

\section{Lung inflammation}

Broncho-alveolar lavage fluid (BAL) analysis was performed as previously described [38]. Briefly, a 20 gauge angiocatheter was inserted into the trachea and secured in place with a 4.0 silk suture. The lungs were lavaged by infusing and then aspirating four aliquots of normal saline $(0.5 \mathrm{ml}$ each) into the lungs. The BAL obtained was then centrifuged for $5 \mathrm{~min}$. The cells were washed with normal saline and quantified using a hemocytometer. Cells were suspended in $1000 \mu \mathrm{l}$ of normal saline and affixed to slides using an Eppendorf centrifuge. BAL cell counts were performed on the cytospin preparations after Giemsa staining. Lung inflammation was also assessed by immunostaining for MAC-3,a macrophage-specific marker, using a monoclonal rat antibody obtained from BD Biosciences (1:20,San Jose, CA). The number of MAC- $3^{\text {pos }}$ cells in the alveolar air spaces was counted from 10 random images taken with the 20X objective on each slide.

\section{Real time RT-PCR}

Total RNA was isolated from lung tissue stabilized in RNAlater using RNeasy Midi Kit (Qiagen, Inc. Valencia, CA) as per manufacturer instructions. Tissues were disrupted and homogenized using a rotor-stator-homogenizer (Ultra-Turrax T8, IKA Works, Wilmington, NC). Samples were centrifuged for $15 \mathrm{~min}$ at $12,000 \times \mathrm{g}$ at $4{ }^{\circ} \mathrm{C}$. The upper 
aqueous phase was transferred to a new collection tube, and an equal volume of $70 \%$ ethanol was added and vortexed. Following step centrifugation at $10,000 \times \mathrm{g}$, RNA was eluted using 30 50 $\mu \mathrm{l}$ RNase-free water. RNA purity and concentration were determined by NanoDrop 1000 Spectrophotometer (Thermo Fisher Scientific, Waltham, MA). Total RNA $(2 \mu \mathrm{g})$ was reverse transcribed using a firststrand cDNA synthesis kit according to manufacturer's protocol (Superscript VI VILO Master Mix with ezDNase Ensyme, Thermo Fisher Scientific). This kit contains ezDNase enzyme which is a double-strand specific thermolabile DNase that is used to remove gDNA contamination from template RNA prior to the RT reaction. Real time RT-PCR using TaqMan ${ }^{\text {Tu }}$ Fast Advanced Master Mix (Applied Biosystems, Foster City, CA) was performed on an ABI Fast 7500 system (Applied Biosystems) using a standard cycling protocol. Primers for rat SDF-1 (Rn00573260), 18S (Rn4332641) and GAPDH (Rn99999916) were pre-developed by Applied Biosystems. The mRNA expression levels of target genes were normalized to $18 \mathrm{~S}$ and GAPDH. Since either normalization yielded similar results, data are reported with normalization to $18 \mathrm{~S}$.

\section{Western blot analysis}

The protein expression of Interleukin-1 $\beta$ (IL-1 $\beta$ ), Interleukin-10 (IL-10), vascular endothelial growth factor receptor-2 (VEGFR-2), and SDF-1 in lung homogenates was determined by Western Blot analysis. The polyclonal antibodies for VEGFR2 (1:200) and IL10 (1:2000) were obtained from Abcam (Cambridge, MA). The polyclonal antibody for SDF-1 (1:50) and mouse monoclonal antibody for IL-1 $\beta$ (1:1000) were obtained from Cell Signaling Technology (Danvers, MA). Total protein was extracted from frozen lung tissues with a RIPA buffer according to the manufacturer's protocol (Santa Cruz, Dallas, TX). Protein concentration was measured by $\mathrm{BCA}$ protein assay using a commercial kit from Pierce Biotechnology Inc. (Rockford, IL). Lung lysate $(50 \mu \mathrm{g} / \mathrm{sample})$ were fractionated by SDS-PAGE on $4-20 \%$ mini-protean Tris-Glycine extended precast protein gel (Bio-Rad, Hercules, CA) and transferred to nitrocellulose membranes (Amersham, Piscataway, NJ). Immunodetection was performed by incubating the membranes with the primary antibodies diluted in blocking buffer overnight at $4{ }^{\circ} \mathrm{C}$ and then for $1 \mathrm{~h}$ at room temperature with horseradish peroxidase-cojugated secondary antibodies. Antibody bound protein was detected using ECL chemiluminescence methodology (Amersham). Band intensity was quantified with Quantity One software (BioRad), with $\beta$-Actin acting as the normalization protein (1:10, 000; Sigma-Aldrich, St. Louis, MO).

\section{Immunohistochemistry and immunofluorescence}

Serial five micrometer $(\mu \mathrm{m})$ paraffin-embedded lung sections were dewaxed and rehydrated in descending grades of alcohol. Following antigen retrieval and blocking of nonspecific binding sites with a protein blocker, the lung sections were incubated overnight at $4{ }^{\circ} \mathrm{C}$ with the appropriate primary antibodies. After washing, the sections were incubated with the appropriate secondary antibodies at room temperature. Sections were evaluated under a fluorescent microscope (Leica DMI 6000, Mannheim, Germany).

\section{Matrigel assay}

The effect of SDF-1 on capillary tube formation was determined by matrigel assay as previously described [39]. HPMECs (Lonza, Allendale, NJ) were cultured to passage 3 to 6 , plated in $100 \mathrm{~mm}$ dishes and serum starved for $48 \mathrm{~h}$. Serum-starved HPMECs were treated with varying doses of recombinant SDF-1 $(10-100 \mathrm{ng} / \mathrm{ml})$ and cultured in normoxic (RA, $5 \% \mathrm{CO}_{2}$ ) or hyperoxic $(95 \%$ $\mathrm{O}_{2}, 5 \% \mathrm{CO}_{2}$ ) conditions for $72 \mathrm{~h}$. Capillary tube formation was assessed on growth factor reduced matrigelcoated wells (BD Biosciences, San Diego, CA). Bright field images were collected at 5 and $20 \mathrm{~h}$. All experiments were done in triplicate and tube formation was quantified by measuring the number and length of capillary-like structures in at least three HPFs per well.

\section{Statistical analysis}

Results, reported as mean \pm standard deviation (SD), were analyzed by two-way ANOVA with post-hoc Holm-Sidak test using SigmaStat software. $P$ values less than 0.05 were considered statistically significant.

\section{Results}

Effect of hyperoxia on lung SDF-1 expression

We first evaluated SDF-1 gene expression in lung homogenates of neonatal pups exposed to 3, 5 and 14 days of hyperoxia. Exposure of neonatal pups to 3 or 5 days of hyperoxia did not alter lung SDF-1 gene expression, Fig. 1a. However, following 14 days of hyperoxia exposure, there was a significant decrease in lung SDF-1 gene expression (RA vs hyperoxia; $P=0.03 ; N=4-5$ /group), Fig. 1a. Double immunofluorescence staining of lung sections with SDF-1 and surfactant protein $C$ or vWF antibodies revealed that SDF-1 is expressed in both lung epithelial and endothelial cells, Fig. 1b and c.

\section{Effective pulmonary delivery of IT JVS-100}

In order to ascertain whether IT administration of a naked plasmid would be an efficient technique to deliver SDF-1 to the lungs, Sprague Dawley pups were given a plasmid expressing luciferase on P3. Significant luciferase activity was detected in the lung on P5, Fig. 2a. While there was still residual activity detected on P14, this was decreased, Fig. 2a. Western blot analysis of P5 and P14 lung homogenates confirmed increased SDF-1 


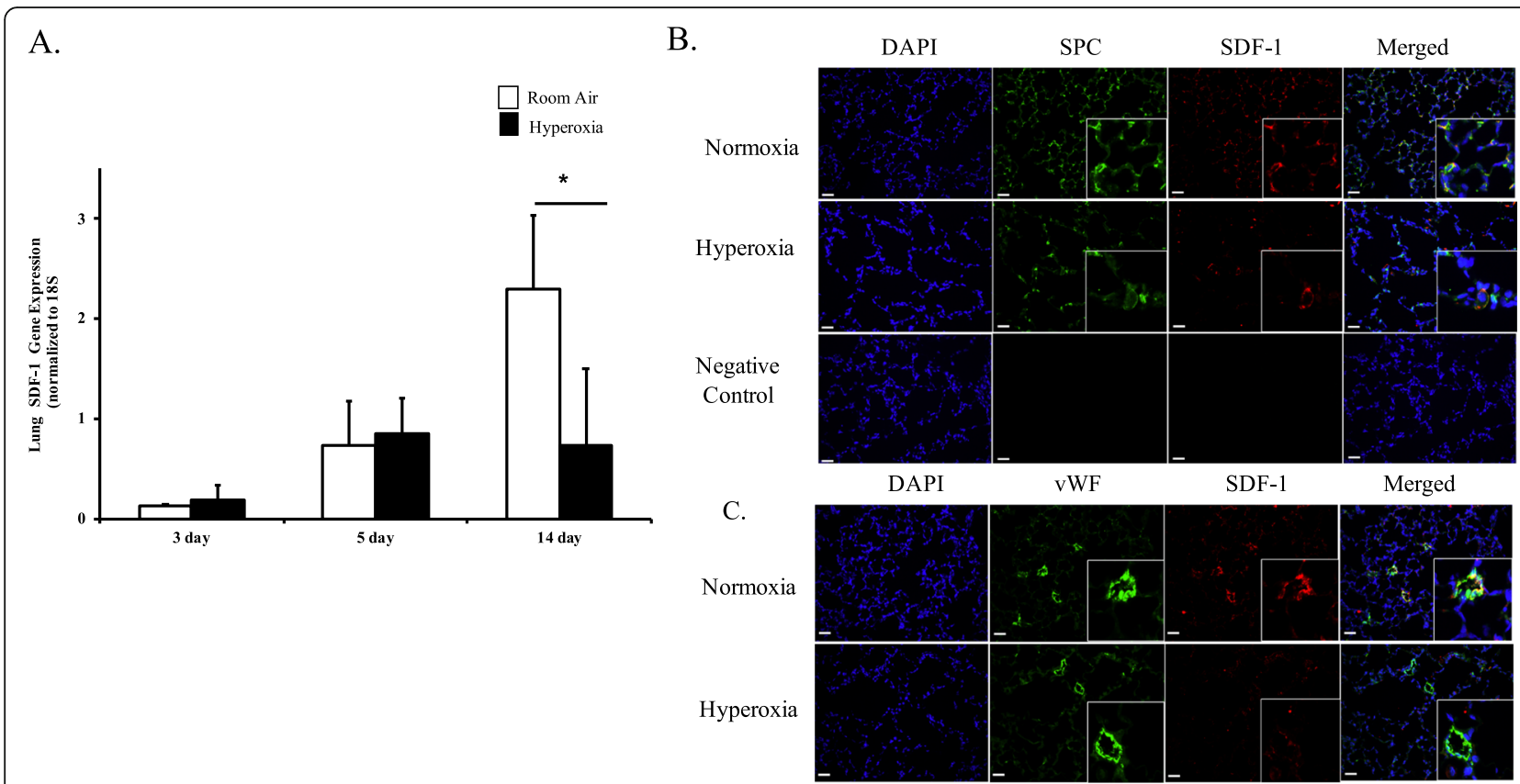

Fig. 1 The effect of hyperoxia on lung SDF-1 expression. a Decreased lung SDF-1 gene expresion in newborn pups exposed to $14 \mathrm{~d}$ of hyperoxia $\left(P<0.05 ;{ }^{*}\right.$ Normoxia vs hyperoxia; $N=4-5$ animals/group). $\mathbf{b}$ Lung sections obtained from 14 day old normoxic and hyperoxic pups stained with SDF-1 (red) and SPC (green) antibodies. SDF-1 ${ }^{\text {pos }}$ SPC ${ }^{\text {pos }}$ cells (yellow) were more abundant in normoxic pups. $\mathbf{c}$ Lung sections stained with SDF-1 (red) and VWF (green) antibodies. SDF-1 ${ }^{\text {pos }}$ WWF $^{\text {pos }}$ cells (yellow) were more abundant in normoxic pups. Scale bar is $50 \mu m$ and original magnification is $\times 200$

protein expression in oxygen exposed rats who received JVS-100, Fig. 2b and c.

\section{JVS-100 improves lung alveolarization in experimental BPD}

Hyperoxia-exposed placebo-treated (Hyperoxia-PL) pups had decreased alveolarization as evidenced by alveolar simplification, Fig. 3a. Radial alveolar count was utilized as a morphometric measure of alveolarization. Whereas hyperoxia-PL pups had a decrease in radial alveolar count ( $8 \pm 0.3$ vs $6 \pm 0.3$; RA-PL vs hyperoxia-PL; $P<$ 0.05; $N=14-19$ animals/group), Fig. 3b, administration of IT JVS-100 increased radial alveolar count in the hyperoxia-exposed pups ( $6 \pm 0.3$ vs $7 \pm 0.4$; hyperoxia-PL vs hyperoxia-JVS-100; $P<0.05 ; \quad N=14-19$ animals/ group), Fig. 3b. Similarly, whereas hyperoxia-PL treated pups had an increase in alveolar septal thickness, this was reduced in JVS-100 treated pups, Fig. 3c.

\section{JVS-100 improves angiogenesis in experimental BPD}

SDF-1 plays a crucial role in angiogenesis [26]. Thus, we next questioned whether IT JVS-100 would improve angiogenesis in neonatal rats exposed to hyperoxia. Exposure of neonatal pups to hyperoxia reduced vascular density, Fig. 4a and b, as evidenced by decreased number of vessels per HPF $(13 \pm 3$ vs $5.8 \pm 0.9$ vessels/HPF; RA$\mathrm{PL}$ vs hyperoxia-PL; $P<0.05 ; N=10$ animals/group).
However, IT administration of JVS-100 modestly improved lung angiogenesis $(5.8 \pm 0.9$ vs. $7.4 \pm 1.4$ vessels/ HPF; hyperoxia-PL vs hyperoxia-JVS-100; $P<0.05$; $N=$ 10 animals/group), Fig. $4 \mathrm{a}$ and $\mathrm{b}$. This was accompanied by a significant increase in lung VEGFR-2 expression in the hyperoxic JVS-100 treated pups (hyperoxia-PL vs hyperoxia-JVS-100; $P<0.05 ; N=6$ animals/group), Fig. 4c. There was no difference in VEGF expression between the hyperoxia groups. In order to confirm the direct pro-angiogenic effects of SDF-1, hyperoxia-exposed HPMECs were treated with varying doses of recombinant SDF-1 (10 or $100 \mathrm{ng} / \mathrm{ml})$ and matrigel assay performed. Hyperoxia-exposed HPMECs had significantly decreased length and number of capillary-like structures. Treatment with recombinant SDF-1 (10 or $100 \mathrm{ng} / \mathrm{ml})$ promoted angiogenesis in hyperoxia-exposed HPMECs as evidenced by increased length and number of capillary-like structures (hyperoxia control vs hyperoxia SDF-10 ng/ml or hyperoxia SDF-100 ng/ml; $P<0.05$; all experiments performed in triplicate), Fig. $4 \mathrm{~d}-\mathrm{f}$. There was no significant effect in the normoxia exposed cells.

\section{JVS-100 attenuates pulmonary hypertension}

Neonatal pups exposed to hyperoxia developed evidence of PH (RVSP: $17 \pm 2$ vs $29 \pm 6 \mathrm{mmHg}$; RA-PL vs hyperoxiaPL; $P<0.05 ; \quad N=19-20$ animals/group and $\mathrm{RV} / \mathrm{LV}+\mathrm{S}$ $(0.32 \pm 0.05$ vs $0.46 \pm 0.08 \mathrm{mmHg} ; \mathrm{RA}-\mathrm{PL}$ vs hyperoxia-PL; 


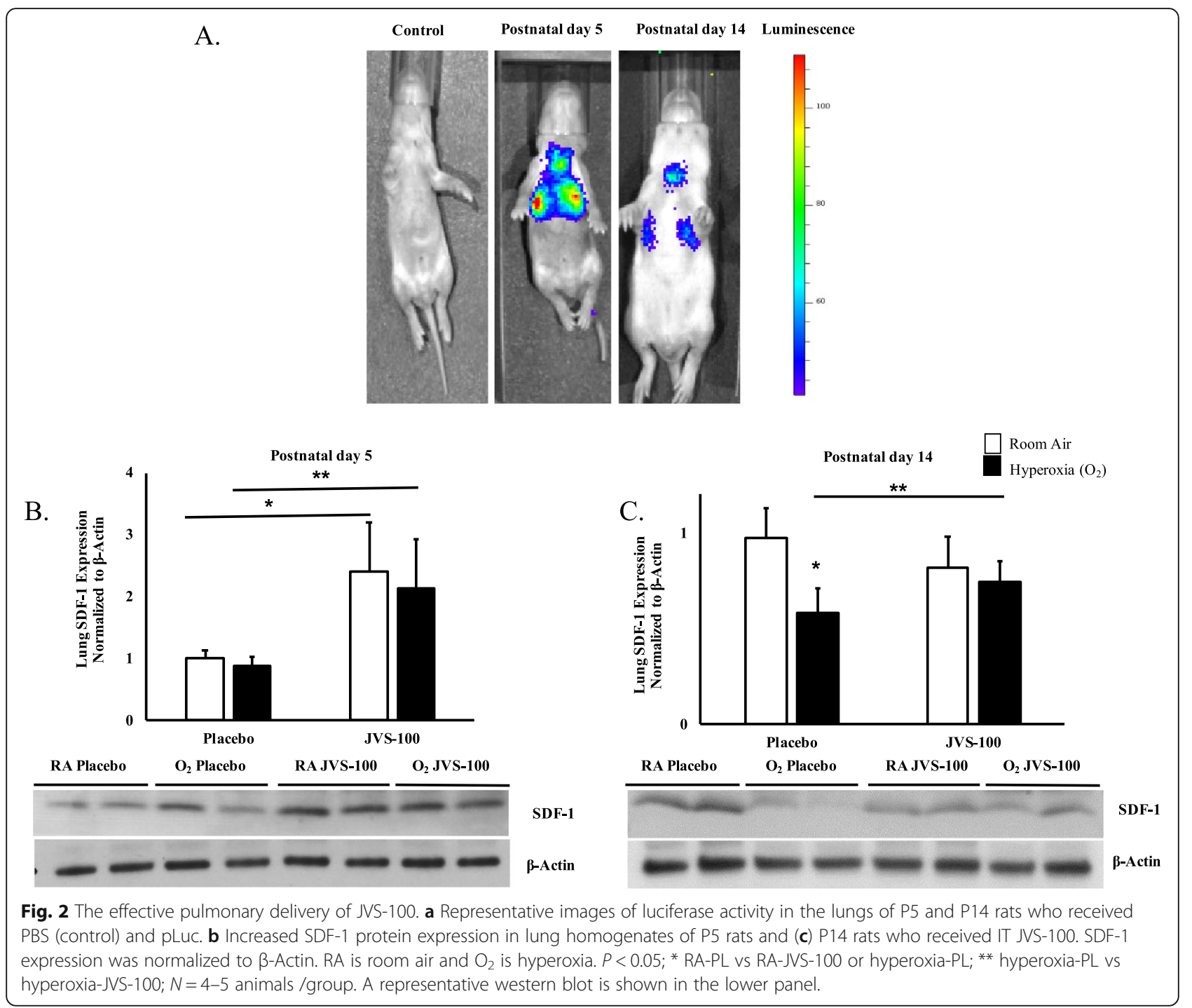

$P<0.05 ; N=19-20$ animals/group), Fig. 5a and b. Both $\mathrm{RVSP}$ and $\mathrm{RV} / \mathrm{LV}+\mathrm{S}$ were reduced after the IT administration of JVS-100 in the hyperoxia-exposed neonatal pups (RVSP: $29 \pm 6$ vs $24 \pm 7 \mathrm{mmHg}$; hyperoxia-PL vs hyperoxiaJVS-100; $P<0.05 ; N=19-20 /$ group and RV/LV + S: $0.46 \pm$ 0.08 vs $0.34 \pm 0.08 \mathrm{mmHg}$; hyperoxia-PL vs hyperoxia-JVS100; $P<0.05 ; N=19-20$ /group), Fig. 5a and b. Together these findings suggest that IT JVS-100 improves PH, a significant component of severe BPD.

Vascular remodeling evidenced by increased muscularized blood vessels is a prominent feature of BPD complicated by $\mathrm{PH}$. Exposure of placebo treated animals to hyperoxia was associated with an increase in the percentage of muscularized blood vessels $(13 \pm 12$ vs $67 \pm$ $12 \%$; RA-PL vs hyperoxia-PL; $P<0.05 ; N=6$ animals/ group), Fig. $5 \mathrm{c}$ and $\mathrm{d}$. In contrast, administration of IT JVS-100 improved hyperoxia-induced pulmonary vascular remodeling in experimental BPD $(67 \pm 12$ vs $44 \pm$
16\%; hyperoxia-PL vs hyperoxia-JVS-100; $P<0.05 ; N=$ 10/group), Fig. 5c and d.

\section{JVS-100 attenuates lung inflammation in experimental BPD}

Lung inflammation is a key feature of BPD. HyperoxiaPL treated pups had an increase in MAC-3 immunostaining $(0.14 \pm 0.25$ vs. $4 \pm 1$ cells/HPF; RA-PL vs hyperoxia-PL; $P<0.05 ; N=10$ animals/group), Fig. 6a and b. Expression of the pro-inflammatory cytokine IL$1 \beta$, previously shown to play an important role in $\mathrm{BPD}$ $[40,41]$ was also increased in the hyperoxia-exposed pups (RA-PL vs hyperoxia-PL; $P<0.05 ; N=5$ animals/ group) Fig. 6c. Interestingly, IT administration of JVS100 to hyperoxia-exposed pups was associated with a decrease in macrophage infiltration $(4 \pm 1$ vs $2.5 \pm 1.7$ vs cells/HPF; hyperoxia-PL vs hyperoxia-JVS-100; $P<0.05$; $N=10$ animals/group), and a reduction in BAL cell 


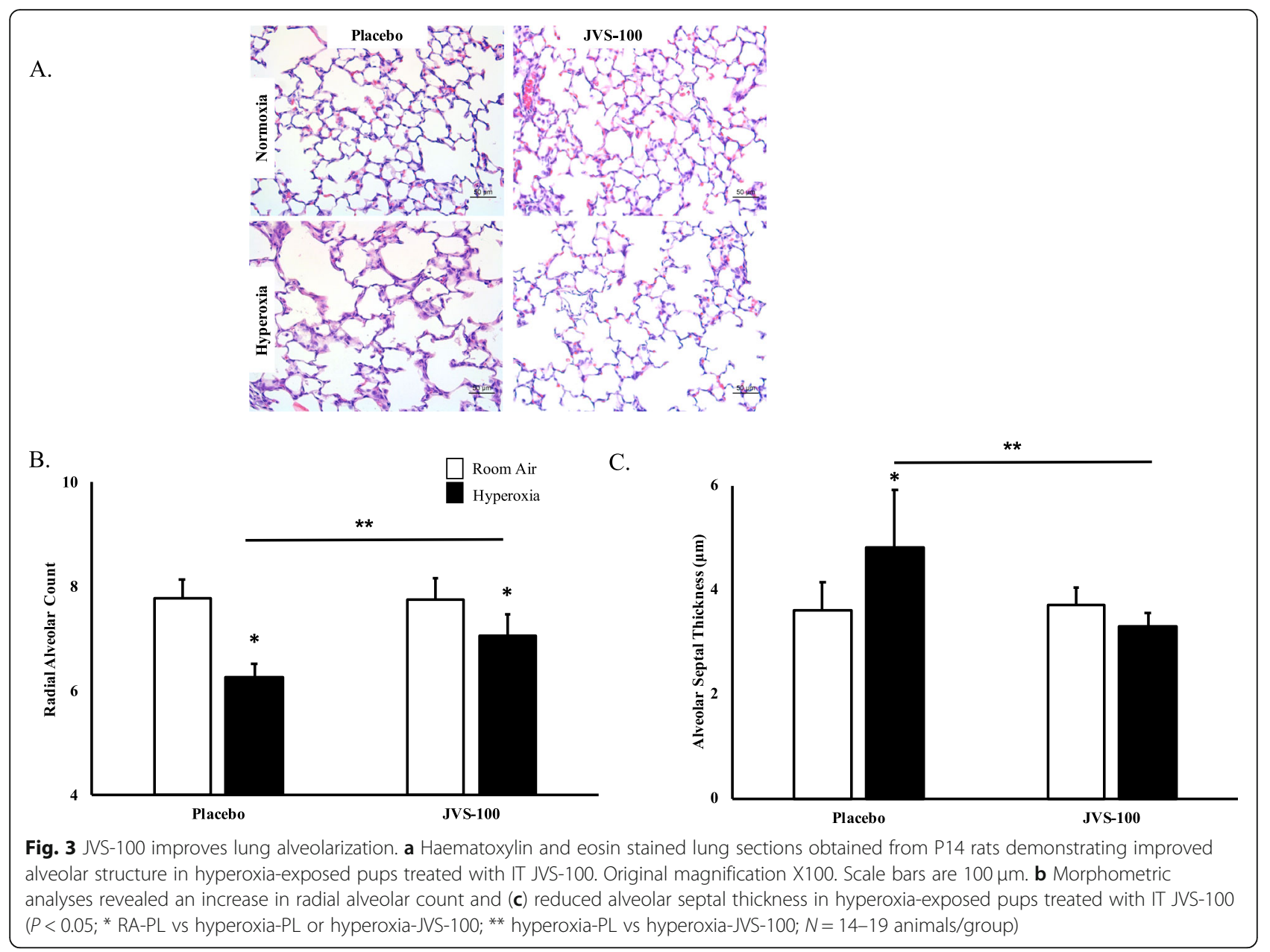

count, Fig. 6a-c. This was accompanied by a decrease in the expression of the pro-inflammatory cytokine IL-1 $\beta$ (hyperoxia-PL vs hyperoxia-JVS-100; $P<0.05 ; N=6$ animals/group), Fig. $6 \mathrm{~d}$, and an increase in the expression of the anti-inflammatory cytokine IL-10 (hyperoxia-PL vs hyperoxia-JVS-100; $P<0.05 ; N=6$ animals/group), Fig. 6e.

\section{Discussion}

Despite advances in neonatal care, BPD continues to be a significant health burden. In the Washington State Medicaid program, chronic respiratory diseases costs were generally higher compared to other chronic illnesses, costing the program in excess of 17 million dollars, with the majority of affected children having BPD or sequelae of prematurity $[42,43]$. Additionally, in the United States, the overall cost of treating premature infants with BPD is approximately 2.4 billion dollars [42]. There is no cure and BPD survivors face high hospital readmission rates, recurrent respiratory illnesses, and other disabling long-term sequelae [6]. In this study, we demonstrate a potential therapeutic role for SDF-1 in preterm infants with BPD.

We show that JVS-100, a non-viral gene therapy engineered to express SDF-1 attenuates lung inflammation and improves angiogenesis in an experimental model of BPD. We demonstrate that lung SDF-1 gene expression is decreased in neonatal pups with experimental BPD. In addition, we show that IT administration of JVS-100 was effectively delivered to the neonatal lung as evidenced by increased SDF-1 protein expression in treated pups. In keeping with our hypothesis, IT JVS-100 improved angiogenesis and pulmonary hypertension in our model of BPD. These findings were accompanied by a reduction in markers of lung inflammation. Together, these findings not only demonstrate that SDF-1 is a mediator of lung repair in experimental BPD but importantly suggests a possible role for this chemokine in the repair of the injured preterm lung.

SDF-1 is a potent chemoattractant known to play a crucial role in organ development, injury, and repair. In 


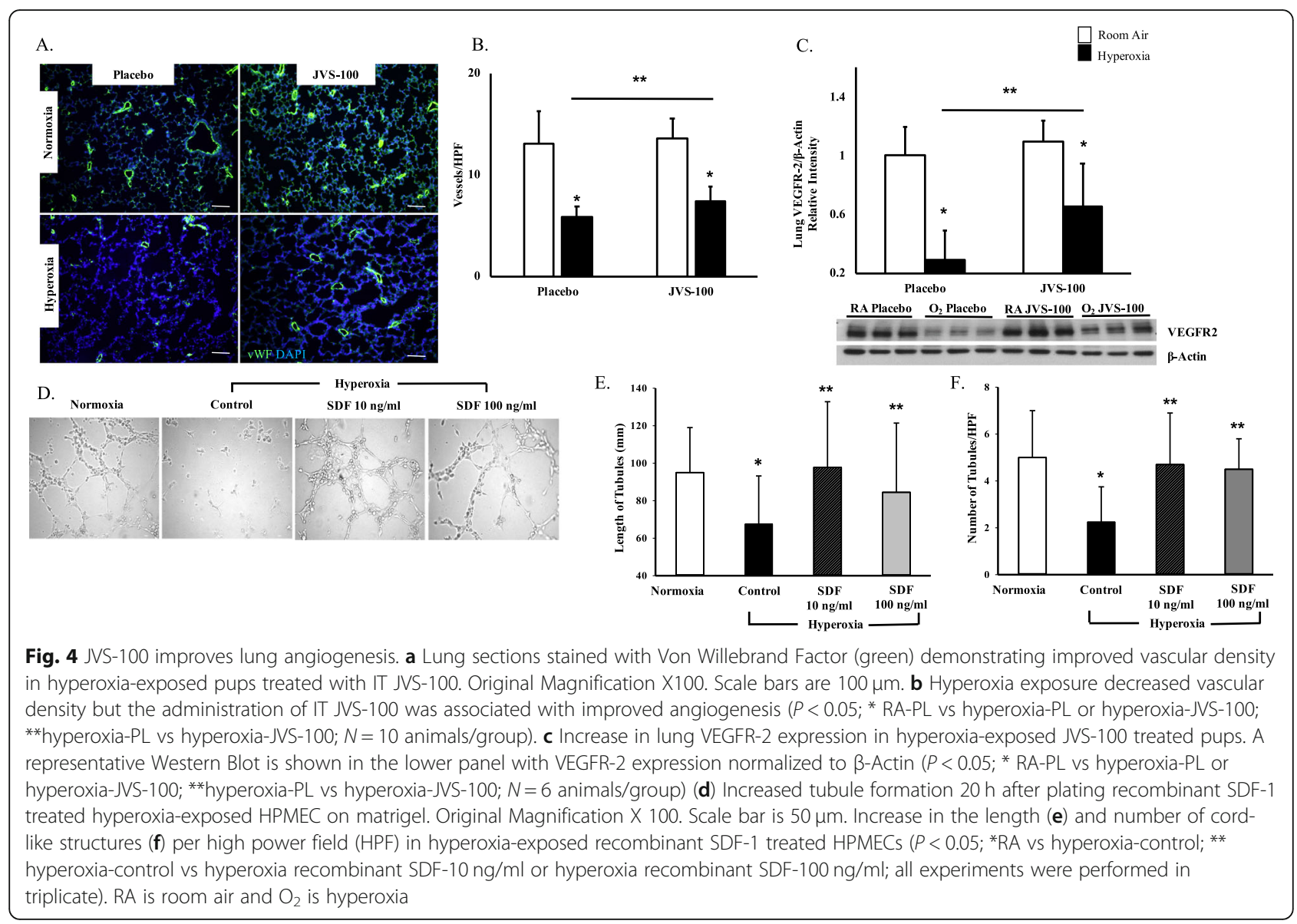

multiple models of injury, SDF-1 enhances organ regeneration by improving angiogenesis [26]. In the present study, we utilized a rodent model of neonatal hyperoxia as it is characterized by lung microvascular damage and decreased angiogenic signalling, similar to that seen in the lungs of preterm infants with BPD [44-46]. We show that following IT JVS-100 treatment, hyperoxiaexposed pups had a modest improvement in angiogenesis as well as an increase in VEGFR2 expression. Consistent with these findings, we also demonstrate increased tube length and branching in hyperoxia-exposed HPMECS treated with recombinant SDF-1. These findings provide further evidence of SDF-1 pro-angiogenic effects and its potential involvement in modulating lung angiogenesis during development.

Interestingly, IT JVS-100 also reduced lung inflammation in experimental BPD. Lung inflammation is a key factor in the pathogenesis of BPD [47-49]. Rindfleisch and colleagues demonstrated that infants who develop BPD have a significant increase in IL-1 $\beta$ [50]. Similar to these findings, in our experimental model of BPD, neonatal pups exposed to hyperoxia also had an increase in IL-1 $\beta$ which was significantly decreased after administration of JVS-100. This was accompanied by an increase in the anti-inflammatory cytokine IL-10 and a decrease in lung macrophage infiltration. Our findings were surprising as other investigators using adult pro-fibrotic disease models have demonstrated that SDF-1 and its receptors have pro-inflammatory effects [9]. They are however in keeping with those of other investigators who show that SDF-1 controls monocyte recruitment to sites of inflammation and also modulates monocyte differentiation towards more pro-angiogenic and anti-inflammatory functions [51]. In addition, SDF-1 regulates IL-10 secretion in $\mathrm{T}$ cells by $\mathrm{T}$-cell receptor (TCR) mediated activation of the mitogen-activated protein kinase cascades (MEK-1/ERK) signalling pathway [52].

Another important finding in our study was a modest improvement in alveolar structure. BPD is characterized by disordered angiogenesis and alveolar simplification. Inhibition of angiogenesis impairs alveolarization in the developing rat lung [53] and in experimental BPD, IT administration of vascular endothelial growth factor promotes angiogenesis and preserves alveolar structure [54] suggesting a link between angiogenesis and alveolarization. Inflammation decreases alveolar septation $[55,56]$ and transgenic adult mice engineered to express the proinflammatory cytokine IL-1 $\beta$ have lung emphysematous 

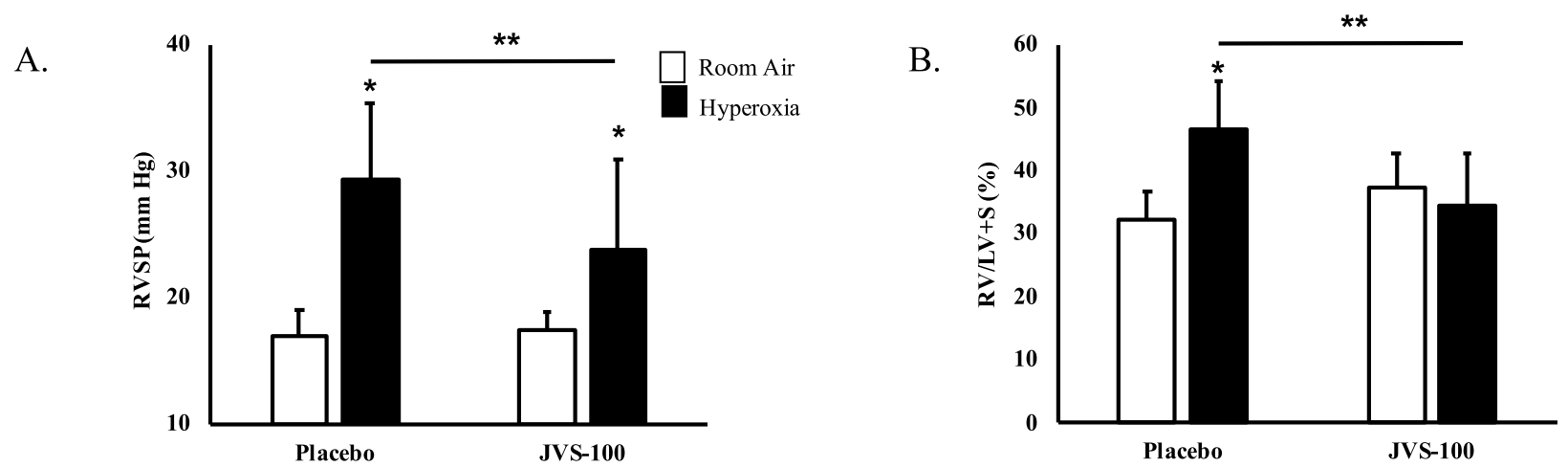

C.

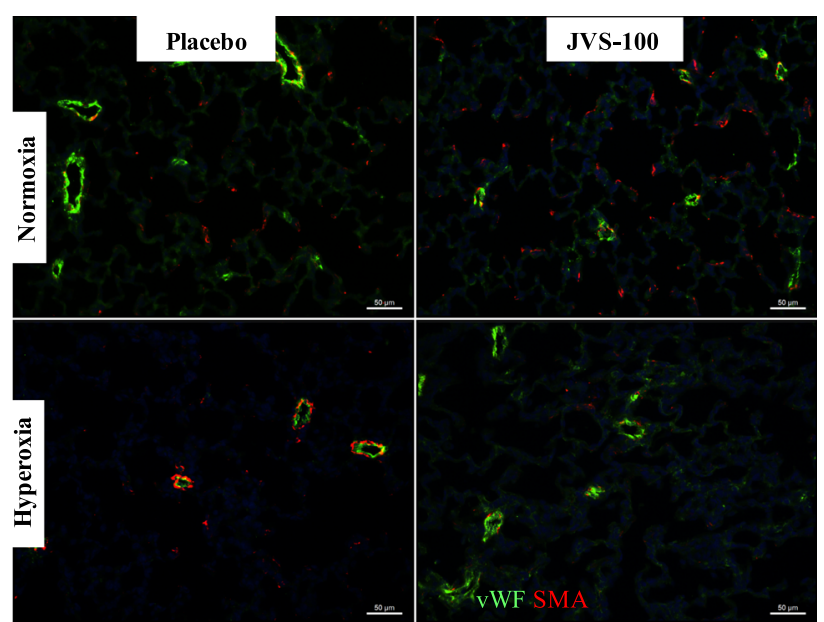

D.

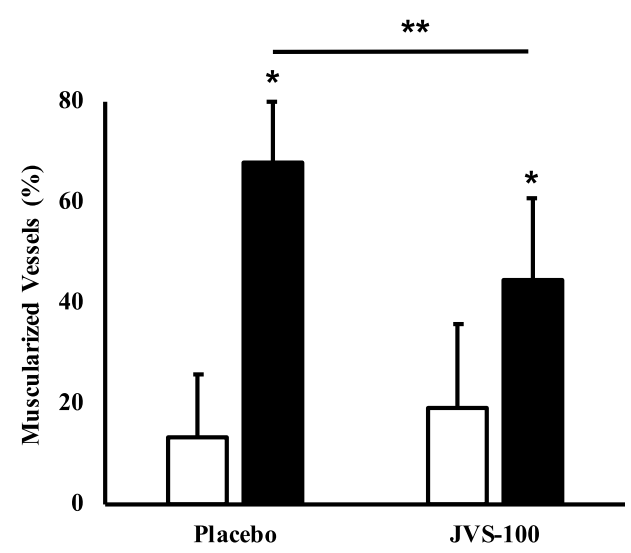

Fig. 5 Effects of JVS-100 on pulmonary hypertension and vascular remodeling in experimental BPD. IT JVS-100 significantly decreased (a) right ventricular systolic pressure (RVSP) and (b) RV/LV + S (weight ratio of right ventricle to left ventricle and septum) in hyperoxia-exposed animals (c) Lung sections stained with a-smooth muscle actin (red) demonstrating improved vascular remodeling in hyperoxia-exposed pups treated with IT JVS-100. Magnification X 200. Scale bars are 50 um. (d) Reduced muscularized vessels in the lungs of hyperoxia-exposed animals after IT JVS-100. $(P<0.05 ;$ * RA-PL vs hyperoxia-PL or hyperoxia-JVS-100; ** hyperoxia-PL vs hyperoxia-JVS-100; $N=19-20$ animals/group)

changes [57]. Our current findings of a modest improvement in alveolar structure suggest that SDF-1 may promote alveolar repair by blunting the inflammatory response and augmenting angiogenesis.

One of the most frequent causes of mortality in BPD is pulmonary hypertension [58-61]. In our current study, IT JVS-100 decreased RVSP, vascular remodelling and right ventricular hypertrophy. While the mechanisms by which PH develop in BPD are still being elucidated, inflammation is a significant player. Patients with pulmonary hypertension have increased levels of IL-1 $\beta$ [62] and overexpression of proinflammatory cytokines induces pulmonary hypertension [63]. We speculate that SDF-1 reduction in inflammation and improvement in angiogenesis may be potential mechanisms by which SDF-1 reduces $\mathrm{PH}$ in experimental BPD.

Our study has several limitations. Our model of BPD is severe. Most babies are usually exposed to lower oxygen concentrations and therefore further studies evaluating milder forms of this disease will be necessary. In addition, although hyperoxia plays a role in the pathogenesis of BPD, there are several other factors including hypoxia, pre-and postnatal exposure to infection, mechanical ventilation and poor nutrition which contribute to this disease. It is therefore possible that the additive effects of these insults on the preterm lung may potentially alter the efficacy of this therapy. Moreover, there are also important differences between our rat model of $\mathrm{BPD}$ and the lung disease evidenced in most preterm infants today. In our present study, rat pups were exposed to hyperoxia from birth to P14, which corresponds to the saccular-alveolar stage of lung development as compared to preterm infants at highest risk for BPD who are mostly in the saccular stage of lung development, with repair and recovery occurring in the alveolar phase. Additionally, JVS-100 is non-viral gene therapy and thus its safety and efficacy in preterm neonates would need to be evaluated. However, JVS-100 use in the myocardium is well studied and has been shown to be safe and effective in patients with ischemic cardiomyopathy $[33,34]$. 


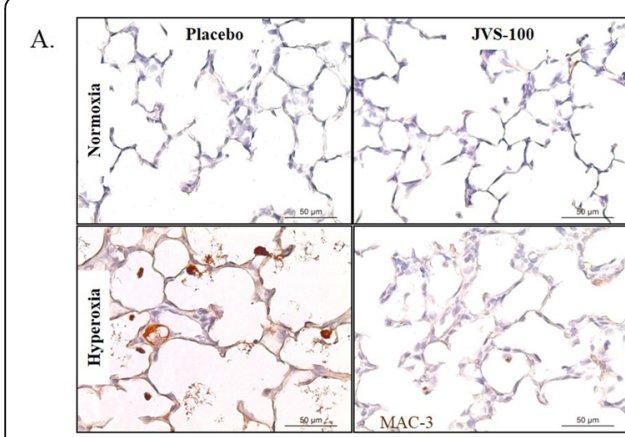

D

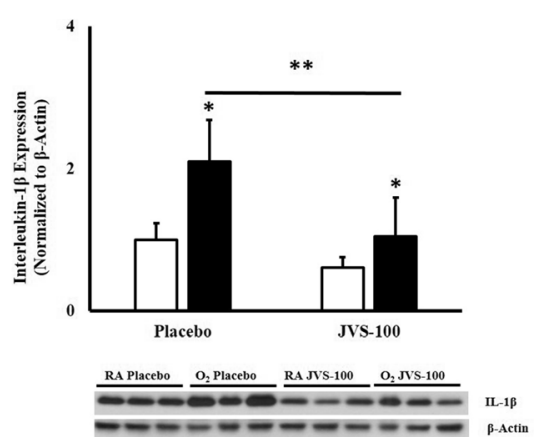

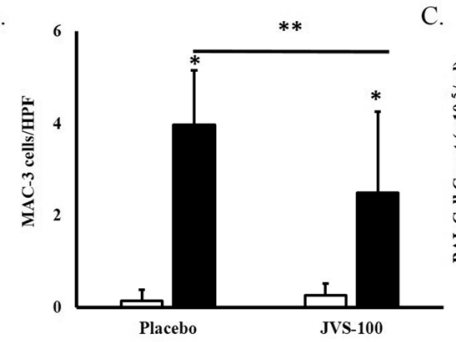

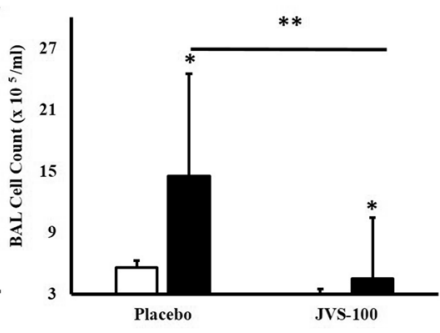

E.

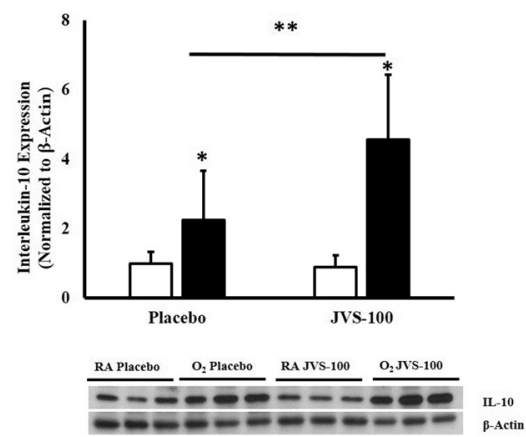

Fig. 6 Anti-inflammatory effects of JVS-100 in experimental BPD. a Lung sections stained with MAC-3 (brown) showing increased MAC-3 positive cells/HPF in hyperoxia-exposed pups. Original magnification X 200. Scale bars are $50 \mu \mathrm{m}$. b IT JVS-100 significantly reduced MAC-3 ${ }^{\text {pos }}$ cells/HPF and (c) BAL cell count in hyperoxia-exposed pups. $\mathbf{d}$ Decrease in the pro-inflammatory cytokine IL-1 $\beta$ and (e) increase in the anti-inflammatory cytokine, IL-10 in the hyperoxia-exposed JVS-100 treated pups $\left(P<0.05 ;{ }^{*}\right.$ RA-PL vs hyperoxia-PL or hyperoxia-JVS-100, **hyperoxia-PL vs hyperoxia-JVS-100; $N=6$ animals/group). A representative Western blot is shown in the lower panel normalized to $\beta$-Actin. RA is room air and $\mathrm{O}_{2}$ is hyperoxia

Furthermore, although we demonstrated that early administration of JVS-100 attenuated lung injury, it will be crucial to perform studies evaluating later administration of JVS-100. It is also important to note that further dose finding studies will be crucial as JVS-100 did not return lung structure to normal and it is not known whether higher doses may have deleterious effects. Our study demonstrates an anti-inflammatory and pro-angiogenic role of SDF-1 after neonatal hyperoxia-induced lung injury. But in other studies, SDF-1/CXCR4 signaling potentiates lung inflammation $[59,60]$. While further studies will be needed to evaluate the effects on SDF-1 on the different macrophage populations within the lung, we speculate that the effects of SDF-1 and its receptors maybe context dependent as most of the other studies were in adult models and SDF-1 may have different roles during development, homeostasis and repair. Indeed, alterations in SDF-1 monomer-dimer equilibrium in different disease states may modulate SDF-1 receptor interaction, signaling, and cell function leading to varying biological effects [29]. After acute injury, selective activation of SDF-1/CXCR7 signaling pathways promotes liver and lung regeneration, however following chronic injury, SDF-1/CXCR4 signaling pathways dominate, provoking fibrosis. Potentially, in our model, early administration of SDF-1, predominantly activated CXCR7 signaling pathways but further studies evaluating SDF-1 signaling, its effects on lung architecture during varying stages of neonatal hyperoxia-induced lung injury will be necessary. Lastly, although not within the scope of this present study, SDF-1 may also improve lung injury by inducing stem cell homing $[17,64,65]$. Cell based therapies which modulate SDF-1 secretion, have been shown to induce stem cell migration and facilitate organ repair [66]. It is therefore plausible that the findings in our study after IT administration of JVS-100 may be secondary to its effect on stem cell migration and modulation .

\section{Conclusion}

The present study provides evidence of a potential reparative role of SDF-1 in neonatal hyperoxisa-induced lung injury. We show that administration of JVS-100, a naked plasmid over-expressing SDF-1, improves lung structure and angiogenesis in rodents with experimental BPD. Although further investigation will be needed, the present study demonstrates that therapies which modulate SDF-1 expression may be potentially efficacious for the prevention and treatment of BPD. 


\section{Abbreviations}

BAL: bronchoalveolar lavage fluid; BPD: bronchopulmonary dysplasia; CXCL12: chemokine ligand 12 aka SDF-1; CXCR4: chemokine receptor 4; CXCR7: chemokine receptor 7; HPF: high power field; HPMEC: human pulmonary microvascular endothelial cell; IT: intra-tracheal; $\mathrm{PH}$ : pulmonary hypertension; RA: room air, normoxia; RV/LV + S: weight ratio of the right ventricle to left ventricle and septum; RVSP: right ventricular systolic pressure; SDF-1: stromal derived factor-1; SPC: surfactant protein C; VEGF: vascular endothelial growth factor; a-SMA: anti-a-smooth muscle actin

\section{Acknowledgements}

Not applicable.

\section{Authors' contributions}

$K G, C B, F D, J H, I S, S D, J H, M S, S S, M B, R Z, S W$ and $K Y$ contributed to the concept and design, analysis and interpretation as well as manuscript drafting. All authors read and approved the final manuscript.

\section{Funding}

The Batchelor Research Foundation Award to KY funded the design of this study, collection, analysis and interpretation of data.

\section{Availability of data and materials}

Please contact author for data requests.

\section{Ethics approval}

This study was approved by the University of Miami Animal Care and Use Committee. Protocol approval number: 15-168.

\section{Consent for publication}

Not applicable.

\section{Competing interests}

The authors declare that they have no competing interests.

\section{Author details}

'Department of Pediatrics, University of Miami Miller School of Medicine, 1580 NW 10th Avenue RM-344, Miami, FL 33136, USA. Batchelor Children's Research Institute, University of Miami Miller School of Medicine, 1580 NW 10th Avenue RM-344, Miami, FL 33136, USA. ${ }^{3}$ The Interdisciplinary Stem Cell Institute, University of Miami Miller School of Medicine, 1580 NW 10th Avenue RM-344, Miami, FL 33136, USA.

Received: 8 February 2019 Accepted: 29 October 2019

\section{Published online: 12 November 2019}

\section{References}

1. Northway WH, Rosan RC, Porter DY. Pulmonary disease following respirator therapy of hyaline-membrane disease. N Engl J Med. 1967;276:357-68.

2. Farstad T, Bratlid D, Medbø S, Markestad T. Norwegian extreme prematurity study group. Bronchopulmonary dysplasia - prevalence, severity and predictive factors in a national cohort of extremely premature infants. Acta Paediatr. 2011;100:53-8.

3. Lemons JA, Bauer CR, Oh W, Korones SB, Papile L-A, Stoll BJ, Verter J, Temprosa M, Wright LL, Ehrenkranz RA, et al. Very low birth weight outcomes of the National Institute of child health and human development neonatal research network, January 1995 Through December 1996 Pediatrics. 2001:107:e1-e1

4. Stoll BJ, Hansen NI, Bell EF, Walsh MC, Carlo WA, Shankaran S, et al. Trends in care practices, morbidity, and mortality of extremely preterm neonates, 1993-2012. JAMA. 2015;314:1039-51.

5. Bhandari A, Mcgrath-Morrow S. Long-term pulmonary outcomes of patients with bronchopulmonary dysplasia. Semin Perinatol. 2013;37:132-7.

6. Eber E, Zach MS. Long term sequelae of bronchopulmonary dysplasia (chronic lung disease of infancy). Thorax. 2001;56:317-23.

7. Gien J, Kinsella JP. Pathogenesis and treatment of bronchopulmonary dysplasia. Curr Opin Pediatr. 2011;23:305-13.

8. Shirozu M, Nakano T, Inazawa J, Tashiro K, Tada H, Shinohara T, et al. Structure and chromosomal localization of the human stromal cell-derived factor 1 (SDF1) gene. Genomics. 1995;28:495-500.
9. Petty JM, Sueblinvong V, Lenox CC, Jones CC, Cosgrove GP, Cool CD, et al. Pulmonary stromal-derived factor-1 expression and effect on neutrophil recruitment during acute lung injury. J Immunol. 2007;178:8148-57.

10. Gerrits $H$, van Ingen Schenau DS, Bakker NEC, van Disseldorp AJM, Strik A, Hermens $L S$, et al. Early postnatal lethality and cardiovascular defects in CXCR7-deficient mice. Genesis. 2008:46:235-45.

11. Ngamsri K-C, Müller A, Bösmüller H, Gamper-Tsigaras J, Reutershan J, Konrad FM. The pivotal role of CXCR7 in stabilization of the pulmonary epithelial barrier in acute pulmonary inflammation. J Immunol. 2017;198 2403-13.

12. Dar A, Kollet O, Lapidot T. Mutual, reciprocal SDF-1/CXCR4 interactions between hematopoietic and bone marrow stromal cells regulate human stem cell migration and development in NOD/SCID chimeric mice. Exp Hematol. 2006;34:967-75.

13. Kucia M, Jankowski K, Reca R, Wysoczynski M, Bandura L, Allendorf DJ, et al. CXCR4-SDF-1 signalling, locomotion, chemotaxis and adhesion. J Mol Histol. 2004;35:233-45.

14. Nagasawa T, Hirota S, Tachibana K, Takakura N, Nishikawa S, Kitamura Y, et al. Defects of B-cell lymphopoiesis and bone-marrow myelopoiesis in mice lacking the CXC chemokine PBSF/SDF-1. Nature. 1996;382:635-8.

15. Ma Q, Jones $D$, Borghesani PR, Segal RA, Nagasawa T, Kishimoto T, et al. Impaired B-lymphopoiesis, myelopoiesis, and derailed cerebellar neuron migration in CXCR4- and SDF-1-deficient mice. Proc Natl Acad Sci U S A. 1998:95:9448-53.

16. Chen W-C, Tzeng Y-S, Li H, Tien W-S, Tsai Y-C. Lung defects in neonatal and adult stromal-derived factor?1 conditional knockout mice. Cell Tissue Res. 2010;342:75-85.

17. Askari AT, Unzek S, Popovic ZB, Goldman CK, Forudi F, Kiedrowski M, et al. Effect of stromal-cell-derived factor 1 on stem-cell homing and tissue regeneration in ischaemic cardiomyopathy. Lancet. 2003;362:697-703.

18. Oliver JA, Maarouf O, Cheema FH, Liu C, Zhang Q-Y, Kraus C, et al. SDF-1 activates papillary label-retaining cells during kidney repair from injury. AJP Ren Physiol. 2012;302:F1362-73.

19. Mavier P, Martin N, Couchie D, Préaux A-M, Laperche Y, Zafrani ES. Expression of stromal cell-derived factor-1 and of its receptor CXCR4 in liver regeneration from oval cells in rat. Am J Pathol. 2004;165:1969-77.

20. Lee J, Marrero L, Yu L, Dawson LA, Muneoka K, Han M. SDF-1a/CXCR4 signaling mediates digit tip regeneration promoted by BMP-2. Dev Biol. 2013;382:98-109.

21. Hunger $C$, Ödemis $V$, Engele J. Expression and function of the SDF-1 chemokine receptors CXCR4 and CXCR7 during mouse limb muscle development and regeneration. Exp Cell Res. 2012;318:2178-90.

22. Imitola J, Raddassi K, Park KI, Mueller F-J, Nieto M, Teng YD, et al. Directed migration of neural stem cells to sites of CNS injury by the stromal cellderived factor 1alpha/CXC chemokine receptor 4 pathway. Proc Natl Acad Sci U S A. 2004;101:18117-22.

23. Enzmann V, Lecaudé S, Kruschinski A, Vater A. CXCL12/SDF-1-dependent retinal migration of endogenous bone marrow-derived stem cells improves visual function after pharmacologically induced retinal degeneration. Stem Cell Rev Reports. 2017;13:278-86.

24. Abbott JD, Huang Y, Liu D, Hickey R, Krause DS, Giordano FJ. Stromal cellderived factor-1a plays a critical role in stem cell recruitment to the heart after myocardial infarction but is not sufficient to induce homing in the absence of injury. Circulation. 2004;110.

25. Yamaguchi J, Kusano KF, Masuo O, Kawamoto A, Silver M, Murasawa S, et al. Stromal cell-derived factor-1 effects on ex vivo expanded endothelial progenitor cell recruitment for ischemic neovascularization. Circulation. 2003;107:1322-8.

26. Petit I, Jin D, Rafii S. The SDF-1-CXCR4 signaling pathway: a molecular hub modulating neo-angiogenesis. Trends Immunol. 2007;28:299-307.

27. Xu J, Mora A, Shim H, Stecenko A, Brigham KL, Rojas M. Role of the SDF-1/ CXCR4 Axis in the pathogenesis of lung injury and fibrosis. Am J Respir Cell Mol Biol. 2007;37:291-9.

28. Drummond S, Ramachandran S, Torres E, Huang J, Hehre D, Suguihara C, et al. CXCR4 blockade attenuates Hyperoxia-induced lung injury in neonatal rats. Neonatology. 2015;107:304-11.

29. McClendon J, Redente EF, Ito Y, Colgan SP, Ahmad A, Tuder R, Mason RJ, Henson PM, Zemans RL: Hypoxia-Inducible Factor-Dependent CXCR4/SDF1 Signaling Promotes Alveolar Type II Cell Spreading and the Resolution of Epithelial Permeability after Lung Injury. Annals of the American Thoracic Society 2015, 12:S72-S73. 
30. Cao Z, Lis R, Ginsberg M, Chavez D, Shido K, Rabbany SY, et al. Targeting of the pulmonary capillary vascular niche promotes lung alveolar repair and ameliorates fibrosis. Nat Med. 2016;22:154-62.

31. Rafii S, Cao Z, Lis R, Siempos II, Chavez D, Shido K, et al. Platelet-derived SDF-1 primes the pulmonary capillary vascular niche to drive lung alveolar regeneration. Nat Cell Biol. 2015;17:123-36.

32. Balasubramaniam V, Mervis CF, Maxey AM, Markham NE, Abman SH Hyperoxia reduces bone marrow, circulating, and lung endothelial progenitor cells in the developing lung: implications for the pathogenesis of bronchopulmonary dysplasia. Am J Physiol Lung Cell Mol Physiol. 2007; 292:L1073-84.

33. Penn M, Pastore J, Miller T, Aras R. SDF-1 in myocardial repair. Gene Ther. 2012;19:583-7.

34. Chung ES, Miller L, Patel AN, Anderson RD, Mendelsohn FO, Traverse J, et al. Changes in ventricular remodelling and clinical status during the year following a single administration of stromal cell-derived factor-1 non-viral gene therapy in chronic ischaemic heart failure patients: the STOP-HF randomized phase II trial. Eur Heart J. 2015;36:2228-38.

35. Penn MS, Mendelsohn FO, Schaer GL, Sherman W, Farr M, Pastore J, et al. An open-label dose escalation study to evaluate the safety of Administration of Nonviral Stromal Cell-Derived Factor-1 plasmid to treat symptomatic ischemic heart failure. Circ Res. 2013;112:816-25.

36. Young KC, Torres E, Hatzistergos KE, Hehre D, Suguihara C, Hare JM. Inhibition of the SDF-1/CXCR4 Axis attenuates neonatal hypoxia-induced pulmonary hypertension. Circ Res. 2009;104:1293-301.

37. Sutsko RP, Young KC, Ribeiro A, Torres E, Rodriguez M, Hehre D, et al. Longterm reparative effects of mesenchymal stem cell therapy following neonatal hyperoxia-induced lung injury. Pediatr Res. 2013;73:46-53.

38. Alapati D, Rong M, Chen S, Hehre D, Rodriguez MM, Lipson KE, et al. Connective tissue growth factor antibody therapy attenuates Hyperoxiainduced lung injury in neonatal rats. Am J Respir Cell Mol Biol. 2011;45: 1169-77.

39. Miranda LF, Rodrigues CO, Ramachandran S, Torres E, Huang J, Klim J, et al. Stem cell factor improves lung recovery in rats following neonatal hyperoxia-induced lung injury. Pediatr Res. 2013;74:682-8.

40. Kotecha S, Wilson L, Wangoo A, Silverman M, Shaw RJ. Increase in interleukin (IL)-1 $\beta$ and IL-6 in Bronchoalveolar lavage fluid obtained from infants with chronic lung disease of prematurity. Pediatr Res. 1996:40:250-6.

41. Kakkera DK, Siddiq MM, Parton LA. Interleukin-1 balance in the lungs of preterm infants who develop bronchopulmonary dysplasia. Biol Neonate. 2005;87:82-90.

42. Ireys HT, Anderson GF, Shaffer TJ, Neff JM. Expenditures for care of children with chronic illnesses enrolled in the Washington State Medicaid Program, fiscal year 1993. Pediatrics. 1997;100:197-204.

43. Bhandari A, Carroll C, Bhandari V. BPD following preterm birth: a model for chronic lung disease and a substrate for ARDS in childhood. Front Pediatr. 2016;4:60.

44. Roberts RJ, Weesner KM, Bucher JR. Oxygen-induced alterations in lung vascular development in the newborn rat. Pediatr Res. 1983;17:368-75.

45. Hosford GE, Olson DM. Effects of hyperoxia on VEGF, its receptors, and HIF2alpha in the newborn rat lung. Am J Physiol Lung Cell Mol Physiol. 2003; 285:L161-8.

46. Maniscalco WM, Watkins RH, D'Angio CT, Ryan RM. Hyperoxic injury decreases alveolar epithelial cell expression of vascular endothelial growth factor (VEGF) in neonatal rabbit lung. Am J Respir Cell Mol Biol. 1997;16: 557-67.

47. Groneck P, Götze-Speer B, Speer CP, Oppermann M, Eiffert H. Association of Pulmonary Inflammation and Increased Microvascular Permeability during the development of bronchopulmonary dysplasia: a sequential analysis of inflammatory mediators in respiratory fluids of high-risk preterm neonates. Pediatrics. 1994;93:712-8

48. Bancalari E. Epidemiology and Risk Factors for the "New" Bronchopulmonary Dysplasia. NeoReviews. 2000;1(1):e2-e5.

49. Jobe AJ. The New BPD: An arrest of lung development. Pediatr Res 1999;46: 641-641.

50. Rindfleisch MS, Hasday JD, Taciak V, Broderick K, Viscardi RM. Potential role of interleukin-1 in the development of bronchopulmonary dysplasia. J Interf Cytokine Res. 1996;16:365-73.

51. Sanchez-Martin L, Estecha A, Samaniego R, Sanchez-Ramon S, Vega MA, Sanchez-Mateos P. The chemokine CXCL12 regulates monocyte- macrophage differentiation and RUNX3 expression. Blood. 2011;117:88-97.

52. Kremer KN, Kumar A, Hedin KE. Haplotype-independent costimulation of IL10 secretion by SDF-1/CXCL12 proceeds via AP-1 binding to the human IL10 promoter. J Immunol. 2007;178:1581-8.

53. Jakkula M, Le Cras TD, Gebb S, Hirth KP, Tuder RM, Voelkel NF, et al. Inhibition of angiogenesis decreases alveolarization in the developing rat lung. Am J Physiol Lung Cell Mol Physiol. 2000;279:L600-7.

54. Thébaud B, Ladha F, Michelakis ED, Sawicka M, Thurston G, Eaton F, et al. Vascular endothelial growth factor gene therapy increases survival, promotes lung angiogenesis, and prevents alveolar damage in Hyperoxia-induced lung injury. Circulation. 2005;112:2477-86.

55. Velten M, Heyob KM, Rogers LK, Welty SE. Deficits in lung alveolarization and function after systemic maternal inflammation and neonatal hyperoxia exposure. J Appl Physiol. 2010;108:1347-56.

56. Cao L, Wang J, Tseu I, Luo D, Post M. Maternal exposure to endotoxin delays alveolarization during postnatal rat lung development. Am J Physiol Lung Cell Mol Physiol. 2009;296:L726-37.

57. Lappalainen U, Whitsett JA, Wert SE, Tichelaar JW, Bry K. Interleukin-1 $\beta$ causes pulmonary inflammation, emphysema, and airway remodeling in the adult murine lung. Am J Respir Cell Mol Biol. 2005;32:311-8.

58. Khemani E, McElhinney DB, Rhein L, Andrade O, Lacro RV, Thomas KC, et al. Pulmonary artery hypertension in formerly premature infants with bronchopulmonary dysplasia: clinical features and outcomes in the surfactant era. Pediatrics. 2007;120:1260-9.

59. An HS, Bae EJ, Kim GB, Kwon BS, Beak JS, Kim EK, et al. Pulmonary hypertension in preterm infants with bronchopulmonary dysplasia. Korean Circ J. 2010;40:131.

60. Mourani PM, Sontag MK, Younoszai A, Miller Jl, Kinsella JP, Baker CD, et al. Early pulmonary vascular disease in preterm infants at risk for Bronchopulmonary dysplasia. Am J Respir Crit Care Med. 2015;191:87-95.

61. Kim GB. Pulmonary hypertension in infants with bronchopulmonary dysplasia. Korean J Pediatr. 2010;53:688-93.

62. Humbert M, Monti G, Brenot F, Sitbon O, Portier A, Grangeot-Keros L, et al. Increased interleukin-1 and interleukin-6 serum concentrations in severe primary pulmonary hypertension. Am J Respir Crit Care Med. 1995;151: 1628-31.

63. Steiner MK, Syrkina OL, Kolliputi N, Mark EJ, Hales CA, Waxman AB. Interleukin-6 overexpression induces pulmonary hypertension. Circ Res. 2009;104:236-44.

64. Aiuti A, Webb IJ, Bleul C, Springer T, Gutierrez-Ramos JC. The chemokine SDF-1 is a chemoattractant for human CD34+ hematopoietic progenitor cells and provides a new mechanism to explain the mobilization of CD34+ progenitors to peripheral blood. J Exp Med. 1997;185:111-20.

65. Son B-R, Marquez-Curtis LA, Kucia M, Wysoczynski M, Turner AR, Ratajczak J, et al. Migration of bone marrow and cord blood mesenchymal stem cells in vitro is regulated by stromal-derived factor-1-CXCR4 and hepatocyte growth factor-c-met axes and involves matrix metalloproteinases. Stem Cells. 2006;24:1254-64.

66. Jungraithmayr W, De Meester I, Matheeussen V, Baerts L, Arni S, Weder W. CD26/DPP-4 inhibition recruits regenerative stem cells via stromal cell-derived factor-1 and beneficially influences ischaemiareperfusion injury in mouse lung transplantation. Eur J Cardiothorac Surg. 2012;41:1166-73.

\section{Publisher's Note}

Springer Nature remains neutral with regard to jurisdictional claims in published maps and institutional affiliations. 